\title{
Professional Growth of Novice and Experienced STEM Teachers
}

\author{
Effrat Akiri $^{1}$ (D) Yehudit Judy Dori ${ }^{1,2}$ (])
}

Accepted: 31 August 2021 / Published online: 16 September 2021

(c) The Author(s) 2021

\begin{abstract}
The first years of teaching are crucial for novice teachers' integration into and retainment in the education system. The support they receive from experienced teachers impacts their professional development. Science, technology, engineering, and mathematics (STEM) teachers require specialized support from domain-specific mentors. In this study, we examined how a three-level mentoring support system contributes to STEM novice teachers' professional growth (PG) and to their mentors. The support system levels are individual mentoring, group mentoring, and mentoring networks. Based on the framework of teachers' professional development, there are three PG dimensions: personal, professional, and social. Our research goal was to analyze teachers' professional growth by the various mentoring level and dimension combinations. The study, conducted using a mixed methods approach, included 123 novice and 78 experienced STEM teachers. We examined the novice teachers' perceptions of their teaching efficacy, the mentoring factors, correlations between the professional growth dimensions, and the contribution of each support level to the growth dimensions. We found that experienced teachers perceive novice teachers' efficacy as lower than that perceived by the novice teachers. We identified gaps between the mentoring factors described by novice and experienced teachers and a strong correlation between the growth dimensions. All three mentoring support levels facilitate substantive personal, professional, and social growth. Individual mentoring contributes the most to all three growth dimensions, followed by mentoring networks. The contribution of this research is its elucidation of the intertwined support levels, which provide scaffolds for the novice teachers and facilitate the growth of the experienced teachers.
\end{abstract}

Keywords Mentoring $\cdot$ Teacher induction $\cdot$ Communities of teachers $\cdot$ Novice teachers $\cdot$ Professional growth

\section{Introduction}

Novice teachers' professional development and their retention in the school system have been investigated. Induction programs are prevalent worldwide to support novice teachers and prevent their attrition, especially during their first two years of teaching (Bower-Phipps et al., 2016; Geva-May \& Dori, 2006; Kohen \& Borko, 2019; Luft et al., 2011; Shwartz \& Dori, 2016, 2020). The foci of this research are mentoring support systems developed for novice science, technology, engineering, and mathematics (STEM) teachers and their contribution to the professional growth (PG) of both novice teachers and the experienced teachers who mentor

Effrat Akiri

effrat@technion.ac.il

1 Technion, Israel Institute of Technology, 3200003 Haifa, Israel

2 Samuel Neaman Institute, Technion City, 3200003 Haifa, Israel them. Novice teachers need support as they construct their competency in pedagogical knowledge (PK) and pedagogical content knowledge (PCK) along with classroom management (Luft et al., 2011; Magnusson et al., 1999; Shwartz \& Dori, 2016). Although the best methods for supporting novice teachers are still being investigated, they seem to prefer support that builds their competence and skills rather than just strengthening their existing knowledge (Janssen \& Lazonder, 2015). Support methods include experienced teachers who mentor novice teachers, professional development (PD) workshops, and participating in a mentoring network, based on a teachers' community and personal relationships that developed during their workshop or study interactions. We elaborate below on each of these methods.

The dynamic nature of the teaching profession requires constant development, which teachers can initiate themselves or via external forces. The role teachers play in their own professional development is substantial for their growth. Bell and Gilbert (1994) defined the professional development framework as consisting of personal, professional, and social development. Professional development is key to personal 
and social transformation and improvement (Sachs, 2016). The development process contributes to teachers' empowerment and can include a wide range of activities (Dehghan, 2020). Since the term professional development is often used to describe workshops rather than actual teachers' development, we use the term "professional growth" to describe the changes and development teachers' experience.

Much has been written about how the challenges faced by novice teachers and the mentoring support they receive affect their professional development. However, there is little research about the contribution of different mentoring support systems to the various aspects of teachers' growth (Parker et al., 2021). In this study, we address this gap and investigate how the different mentoring support levels affect the various teachers' growth dimensions. We also investigated the effect of teaching efficacy on growth in the personal dimension and PG of novice and experienced STEM teachers who participated in individual and group mentoring programs and networks. Previous studies investigated one or two support levels. Our study encompasses the three support levels and three PG dimensions, as it investigates STEM novice teachers at the Technion's Teachers' Induction Unit during their first years of teaching. The Technion is a science and technology research university, which educates science and technology teachers.

\section{Theoretical Background}

This chapter is divided into two sections. The first presents the PG dimensions, based on the professional development framework and self-efficacy theory, and the second describes the three mentoring support levels: individual mentoring, group mentoring, and mentoring networks.

\section{Teachers' Professional Growth (PG)}

Purpose, opportunity, and response guide teachers through past experiences and towards potential futures, as part of the complex process of PG (Taylor, 2020). According to the professional development framework (Bell \& Gilbert, 1994), teachers grow in three dimensions over the course of their careers, namely personally, professionally, and socially (see Fig. 1).

The personal dimension comprises emotional characteristics, including those needed to overcome challenges related to integrating new ideas and methodologies in teaching. Addressing pre-service teachers' beliefs has been found to have an impact on their beliefs about teaching. Teachers find solutions to obstacles and constraints they encounter, which can contribute to their empowerment (Akiri et al., 2021; Bray-Clark \& Bates, 2003). Principals who delegate responsibilities to their teachers can also contribute to their empowerment and thus to their personal development (Lumpkin, 2008). The professional dimension focuses on learning and developing new ideas and activities (Akiri et al., 2020; Avargil et al., 2012). Studies show that teachers who prepare classroom activities improve their sense of ownership and attachment to these activities (Bayar, 2014). The social dimension is related to interpersonal interactions with colleagues. It begins with the understanding that isolation is not ideal, and moves on to cooperating with colleagues and valuing that collaboration (Fitzgerald \& Theilheimer, 2013). The highest level of the social dimension is initiating and developing collaborations and teamwork (McTighe \& Emberger, 2006).

Teachers' ongoing growth not only contributes to their retention in the teaching profession but also improves the quality of their teaching skills. Trained and supported teachers who developed their teaching efficacy and are members of a teachers' community may enhance students' skills and performance (Avargil, 2019; Feiman-nemser, 2012; Vangrieken et al., 2017).

\section{Self-efficacy and Teaching Efficacy}

Bandura (1986) addressed the aspect of self-efficacy in the social cognitive theory. Self-efficacy refers to teachers'
Fig. 1 Teachers' professional development, modified framework
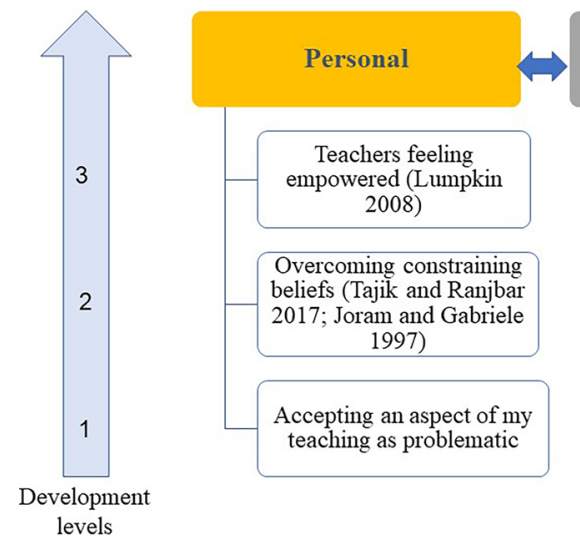
belief in their own ability to achieve optimal performance. It can be developed through direct and indirect personal experiences, verbal persuasion by others, and self-belief that is based on the individuals' emotional perceptions of themselves, which influence teachers' goals, behaviors, and life circumstances (Bandura, 2008, 2012). Teachers' belief in their ability to improve students' learning outcomes is called teaching self-efficacy or teaching efficacy (Siwatu, 2007). Teachers' belief in their own ability to teach science is their science teaching efficacy (RameyGassert et al., 1996). Lower levels of teaching efficacy were found among novice teachers, as experience leads to greater efficacy.

Teaching efficacy is a key element of science teachers' PG (Haney \& Lumpe, 1995; Posnanski, 2002). Professional development workshops can enhance teachers' efficacy in different ways, for example, by simulating situations that teachers face (Bray-Clark \& Bates, 2003). The presence of a role model for the novice teacher to identify with, such as a mentor, can contribute to the novice teacher's efficacy through modeling, feedback, and support. Support from colleagues and a community can also make a significant contribution to teachers' self-beliefs (Tschannen-Moran \& Hoy, 2007; Wenner, 2001).

\section{Mentoring}

Mentorship is a collaborative relationship for learning and working. Effective mentoring is based on trust and shared responsibility (Awaya et al., 2003). It benefits all the parties involved by increasing the mentees' teaching efficacy, providing substantial professional development, and improving problem solving abilities, self-esteem, and identity formation. Empowering novice teachers can also enhance experienced teachers' self-efficacy and refine their teaching skills (Aspfors \& Fransson, 2015; Hudson, 2013). Mentors reflect upon their teaching practices, learn from their mentees, and gain new perspectives (Fairbanks et al., 2000; Fantilli $\&$ McDougall, 2009).

Research about mentoring generally focuses on mentoring pre-service and novice in-service teachers (Bradbury, 2010; Canipe \& Gunckel, 2020; Feiman-nemser, 2012; Hudson, 2004; Luft et al., 2011; Richmond et al., 2020). In our research, this term refers only to novice in-service teachers.

Typical mentoring generally involves one mentor and one mentee (Hudson, 2013; Richter et al., 2013). However, the definition of mentoring has been expanded to include different structures such as group mentoring and mentoring networks (Byars-Winston \& Dahlberg, 2019). In this section, we will present individual mentoring, group mentorship, and mentoring networks.

\section{Individual STEM Mentoring}

STEM education involves coursework and laboratory training, extending to many other areas, such as communicating ideas clearly. Mentoring in STEM aims to support novice STEM teachers who encounter these diverse aspects of the profession. A mentor with the relevant PK can provide interpersonal support and foster the novice teachers' pedagogy, morale, and sense of belonging, thus contributing to retention (Aspfors \& Fransson, 2015; Hudson, 2004).

Mentoring includes pairing experienced teachers (mentors) with novice ones (mentees) (Richter et al., 2013). The process can be defined and performed in several ways (Geva-May \& Dori, 2006). One definition is “.... process, and a long-term relationship between an experienced teacher (mentor) and a less experienced novice teacher, that is primarily designed to support the novice teachers' learning, professional development, confidence, and wellbeing and to facilitate their induction into the culture of teaching..." (Aspfors \& Fransson, 2015, p. 76). Mentoring can also be thought of as a shared journey or as a professional or developmental relationship that deepens over time (Awaya et al., 2003; Fletcher \& Mullen, 2012; Parker et al., 2021).

Educative mentoring supports novice teachers' immediate needs and helps them achieve their long-term goals. Mentors foster novice teachers' growth by identifying their needs, reinforcing inquiry, introducing various solutions for teaching challenges, and treating them as equals. The equal voice of both teachers in the mentoring relationship also facilitates new reforms and strategy implementations, as the novice teachers are exposed to contemporary ideas during their training and are more likely to pursue them (Bradbury, 2010).

Hudson et al. (2005) presented five factors for effective STEM mentoring: personal attributes, system requirements, PK, modeling, and feedback. These factors should be addressed by STEM mentors and novice teachers as part of the individual mentoring process.

\section{Group Mentorship: Professional Development Workshops}

In group mentorship programs, a group of teachers work with one or more mentors. The participants share peer advice, information, and resources with each other and receive guidance from the mentors, who enlighten them with new perspectives and discipline viewpoints (Byars-Winston \& Dahlberg, 2019). 
PDs aim at transforming teachers' knowledge into practice (Avalos, 2011). The PD workshops offer learning opportunities for teachers interested in maintaining and improving their professional credentials and involve learning opportunities. Participation in a PD workshop improves the teacher's understanding of the profession and of the teachers' role (Avalos, 2011; Bell \& Gilbert, 1994; Dori \& Herscovitz, 2005). Teachers' beliefs and practices can change during a PD program (Ketelhut et al., 2020), as they gain a better understanding of their role in the process and strengthen their self-efficacy. Reflection, which is emphasized in PD, is a tool that can enhance cognition and improve practices (Avalos, 2011; Kohen \& Borko, 2019; Wenner, 2001).

Diverse professional development programs, which may serve as group mentoring, can explain why experienced teachers often possess a broader perspective and more general knowledge than novice teachers (Luft et al., 2011). PCK develops through these professional development programs as well as while teaching in class and working with students.

Teachers' PG occurs through a variety of experiences, including teaching training, PD programs, taking on additional responsibilities in school, and interacting with their peers or students. These experiences can be individual, such as interacting with a mentor or group activities, in which all the novice teachers are gathered in their university or college and discussed the challenges they face. One example of an individual professional development process is self-video-based discourse, which has been found to contribute to the teachers' awareness and help them focus on the subject matter (Lehavi et al., 2019). Another example is the mentoring process, where the mentors build novice teachers' PG in areas of their own expertise (Aspfors \& Fransson, 2015).

\section{Mentoring Network: Teachers' Communities}

In his monograph, Shulman (1997) presented an analogy between a community of learners and community of teachers. In a community of learners, a benchmark is set for creating common knowledge base and goals while the community works together. This process often presents unexpected turns along the way, as it involves exploration. According to Shulman, the same principle that applies to students who learn in a community of learners can also happen in a community of teachers while exploring and learning how to cope when reality collides with their plans, as usually happens in real life. Mentoring networks of this kind enable their members, both the mentors and their mentees, to engage in learning activities and to learn and reflect with peers and a facilitator (Mandrikas et al., 2021).

Teaching is not only about cognitive or technical processes; it is based on the quality of human relations. Trust, support, stimulation, and a comfortable relationship are crucial for professional learning (Aspfors \& Bondas, 2013).
Cultivating relationships in school has been known to support increased graduation rates, student engagement, and endured learning. Another benefit is the ability to overcome demographic boundaries such as culture, ethnicity, and age (Zacarian \& Silverstone, 2015). Collaborative mentoring that includes teachers, administrators, and professors who function as a network can synergize relationships and address the complex demands of the novice teacher (Mullen, 2000; Vozzo et al., 2004).

A mentoring network offers an environment in which novice and experienced teachers can develop and learn from each other's challenges and experiences or acquire new knowledge together (Tal et al., 2021). Engaged communities can contribute and enhance STEM learning with knowledge, resources, and feedback (Ellis et al., 2017; Falloon et al., 2020). In the community, all teachers have equal voices, which is empowering for novice teachers (Vangrieken et al., 2017). Teacher communities can also be sustained and supported by social media, which colleagues can use to share information (Haşiloğlu et al., 2020). Blended communities in which teachers participate in both face-to-face and online communities introduce growth opportunities for their teacher members (Trust \& Horrocks, 2017).

Based on the framework of teachers' professional development, which comprises the personal, professional, and social dimensions, our research goals are to analyze teachers' growth in each of the dimensions and assess the contribution of the individual, group, and network mentoring to this growth.

Our research question is:

How do mentors and mentees perceive

(a) The novice teachers' teaching efficacy,

(b) The mentoring process,

(c) The contribution of the mentoring to their PG?

\section{Method}

As part of an induction program at the Technion's Faculty of Education in Science and Technology, the novice STEM teachers receive three support levels during their first 2 years in the profession: (1) individual mentoring by experienced teacher mentors, (2) group mentoring, based on professional development workshops, and (3) mentoring networks.

We analyzed teaching efficacy, mentoring factors, and PG dimensions by collecting qualitative and quantitative data. A convergent parallel mixed methods design was used for data collection and analysis. Data from the interviews, focus groups, and questionnaires was triangulated to provide a deeper understanding of the findings (Creswell \& Creswell, 2017; Creswell \& Clark, 2017). 


\section{Research Setting and Participants}

Participants were 123 novice STEM teachers and 78 mentors who are experienced STEM teachers. All the novice teachers and most mentors participated in professional development workshops conducted at the Technion's Teachers' Induction Unit. Each participant was either a mentor or a mentee, engaged in individual mentoring relationships. Mentors were expected to meet with the novice teachers for individual mentoring sessions on a weekly basis, conduct observations in their classrooms, and provide constructive feedback and support. Group mentoring was conducted in 60-h workshops for firstyear teachers. The meetings were hybrid in nature, with some face-to-face and others online, and incorporated the implementation of a variety of educational technology platforms, such as online assessment, video clips, and simulations. In the workshop, the novice teachers were encouraged to conduct action research in their classrooms, preferably with support from or collaboration with the mentors. Action research was found to produce changes in teaching methods and perceptions (Laudonia et al., 2018; Miedijensky \& Sasson, 2020). The second-year teachers participated in a 30-h workshop that was same length as the mentors' workshop, though the content was different. Each session lasted $4 \mathrm{~h}$ in which teachers grappled with real-life issues while workshop facilitators and peers offered support. Teachers discussed STEM-related topics, class management issues, and how to navigate a STEM education career path. First-year teachers met with the mentors' group and together they developed strategies for addressing contentspecific and pedagogical topics and shared their knowledge and perspectives about personal and professional issues they encountered during their teaching careers. The mentoring network comprised the teachers who participated in all the joint meetings, including first-year, second-year, and experienced teachers, to form a heterogeneous community. Figure 2 presents the research setting.

\section{Tools}

Research tools included open- and closed-ended questionnaires, semi-structured interviews with three pairs of novice teachers and mentors, and two focus groups. The questionnaires comprised the following parts: teaching and general self-efficacy, the MEPST instrument (Hudson et al., 2005), and open-ended questions regarding the participants' perceptions of the mentoring process and the workshops and their effect on the PG of novice teachers. The questionnaires are described in greater detail below. The interviews focused on the relationships between the novice teachers and their mentors. Focus groups were conducted with (a) a group of novice teachers and mentors at the end of the year and with (b) a secondary school mathematics team. A total of 29 teachers were interviewed.

Self-efficacy was measured using the scale of self-efficacy (Jerusalem \& Schwarzer, 2014) at the beginning of the year, based on answers provided by first-year teachers $(N=83)$ and second-year teachers $(N=38)$. We used a teaching efficacy questionnaire based on a modified short form of the Teacher's Sense of Efficacy Scale (TSES) designed by TschannenMoran and Hoy (2001). The questionnaire was answered at the beginning and end of year by the first-year teachers $\left(N_{\mathrm{t}=0}=84\right.$, $\left.N_{\mathrm{t}=1}=54\right)$, and once a year by the second-year teachers $(N=39)$ and the mentors $(N=78)$. The mentors responded to the questionnaire with respect to the novice teachers they mentored $\left(\alpha_{\text {Cronbach }}=0.877\right)$. The questionnaire contained 10 statements that describe different aspects of teaching such as "when I think of my abilities as a novice teacher, I feel I can apply a variety of assessment methods." Novice teachers also completed a general self-efficacy questionnaire $\left(\alpha_{\text {Cronbach }}=0.741\right)$.

The Mentoring for Effective Primary Science Teaching (MEPST) instrument $(N=88)$ was adapted for secondary school (Hudson et al., 2005). Table 1 presents the factors, descriptions, example statements, and reliability measures.

Fig. 2 Research setting

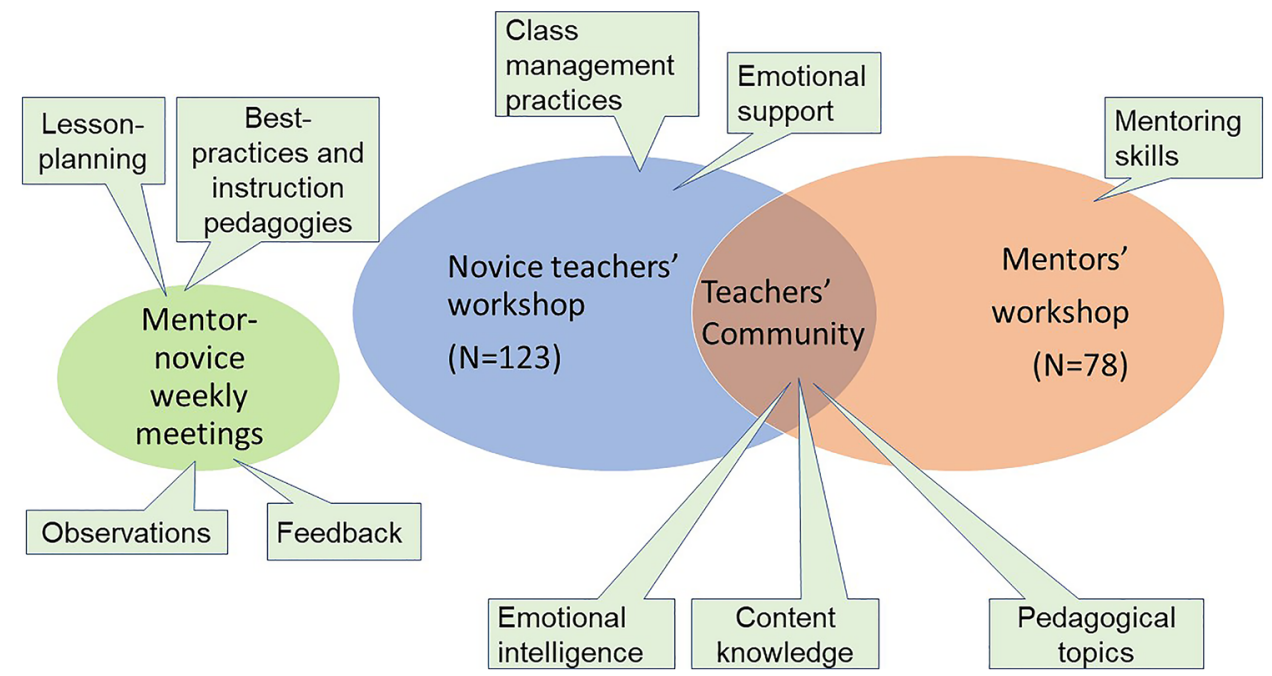


These factors were used to analyze the content of the individual mentoring both quantitatively and qualitatively.

The questionnaires also included open-ended questions regarding perceptions about the mentoring process and the workshops' effect on the PG of the novice teachers $(N=166)$. One example is "How would you describe the optimal effective mentoring relationship?" Interview questions included "Describe your relationship with your mentor" and "How do you think you contributed to the relationship you have with your mentee?".

Qualitative data from the interviews and focus groups were analyzed. Segments from the data were categorized based on the framework of teacher development (Bell \& Gilbert, 1994; Dori \& Herscovitz, 2005) to identify the dimensions of growth (personal, professional, and social) and the mentoring support levels (individual, group, and network) that facilitate teachers' growth. In the first stage, four independent STEM education experts analyzed 36 segments, reaching a 94-97\% level of agreement regarding the growth dimension, and $100 \%$ agreement regarding the support levels. In the next stage, the same experts analyzed an additional 29 statements and reached $96 \%$ agreement regarding the growth dimension and $100 \%$ agreement regarding the support levels. A total of 635 segments were included in the final analysis.

\section{Results}

We begin by presenting teachers' perceptions regarding novice teachers' teaching efficacy. Then, we present teachers' perceptions of the mentoring factors needed for effective mentoring relationships, gathered in a workshop activity and through questionnaires. We then classify the mentoring factors according to the PG dimensions, analyze the correlations between these dimensions, and provide examples. Finally, we discuss the contribution of the mentoring support levels to the teachers' PG.

\section{Perceptions of Teachers Regarding Novice Teachers' Teaching Efficacy}

Our findings show a gradual increase in the novice teachers' teaching efficacy. We also found a significant difference between the teaching efficacy of first- and second-year novice teachers and the perceptions of their mentors regarding the novice teachers' teaching efficacy $\left(F_{(2,252)}=4.821\right.$, $p<.01$ ) (see Fig. 3).

\section{Perceptions Regarding the Mentoring Process}

We begin in presenting example statements regarding the mentoring factors, and a workshop activity conducted in this subject. Then, we compare mentors' and mentees' perceptions regarding these factors, based on the MEPST tool, adapted for secondary school (Hudson et al., 2005). Following, we categorize the mentoring factors into the PG dimensions and analyze the correlations between these dimensions. Table 2 presents examples of statements that the teachers said in the interviews, while describing the mentoring factors.

In a workshop activity at a joint session of novice teachers and mentors, the participants were asked to state the topics they think should be discussed between a mentor and a mentee, and then categorize these topics into the five factors. Figure 4 presents the graph that was created based on novice teachers' descriptions of their needs and expectations (green,

Table 1 Mentoring factors, statement examples, and reliability (Hudson et al., 2005)

\begin{tabular}{|c|c|c|c|}
\hline Factor & Description & Example statement from questionnaire & $\begin{array}{l}\text { Cronbach's alpha } \\
\text { reliability }\end{array}$ \\
\hline Personal attributes & $\begin{array}{l}\text { The ability to frame social interactions within } \\
\text { the right context }\end{array}$ & $\begin{array}{l}\text { During my internship in science teaching, my } \\
\text { mentor made me feel more confident as a science } \\
\text { teacher }\end{array}$ & 0.935 \\
\hline System requirements & $\begin{array}{l}\text { School policies and science curricula are } \\
\text { uniform requirements that assure the "Science } \\
\text { for all" theme }\end{array}$ & $\begin{array}{l}\text { During my internship in science teaching, my } \\
\text { mentor talked to me about the school policies } \\
\text { for science teaching }\end{array}$ & 0.790 \\
\hline Pedagogical knowledge & $\begin{array}{l}\text { Support in effective STEM instruction and other } \\
\text { related aspects (Radloff \& Guzey, 2016), } \\
\text { including lessons planning, teaching strategies, } \\
\text { problem solving, classroom management, } \\
\text { questioning skills, and effective teaching } \\
\text { practice assessment }\end{array}$ & $\begin{array}{l}\text { During my internship in science teaching, my } \\
\text { mentor guided me on science lesson preparation }\end{array}$ & 0.934 \\
\hline Modeling & $\begin{array}{l}\text { Mentors model their teaching based on effective } \\
\text { teaching practices }\end{array}$ & $\begin{array}{l}\text { During my internship in science teaching, my } \\
\text { mentor modeled effective classroom management } \\
\text { when teaching science }\end{array}$ & 0.896 \\
\hline Feedback & $\begin{array}{l}\text { Oral and written feedback and an opportunity } \\
\text { to reflect the novice teacher's practices and } \\
\text { improve them }\end{array}$ & $\begin{array}{l}\text { During my internship in science teaching, my mentor } \\
\text { discussed and explained how she evaluated my } \\
\text { science teaching }\end{array}$ & 0.803 \\
\hline
\end{tabular}




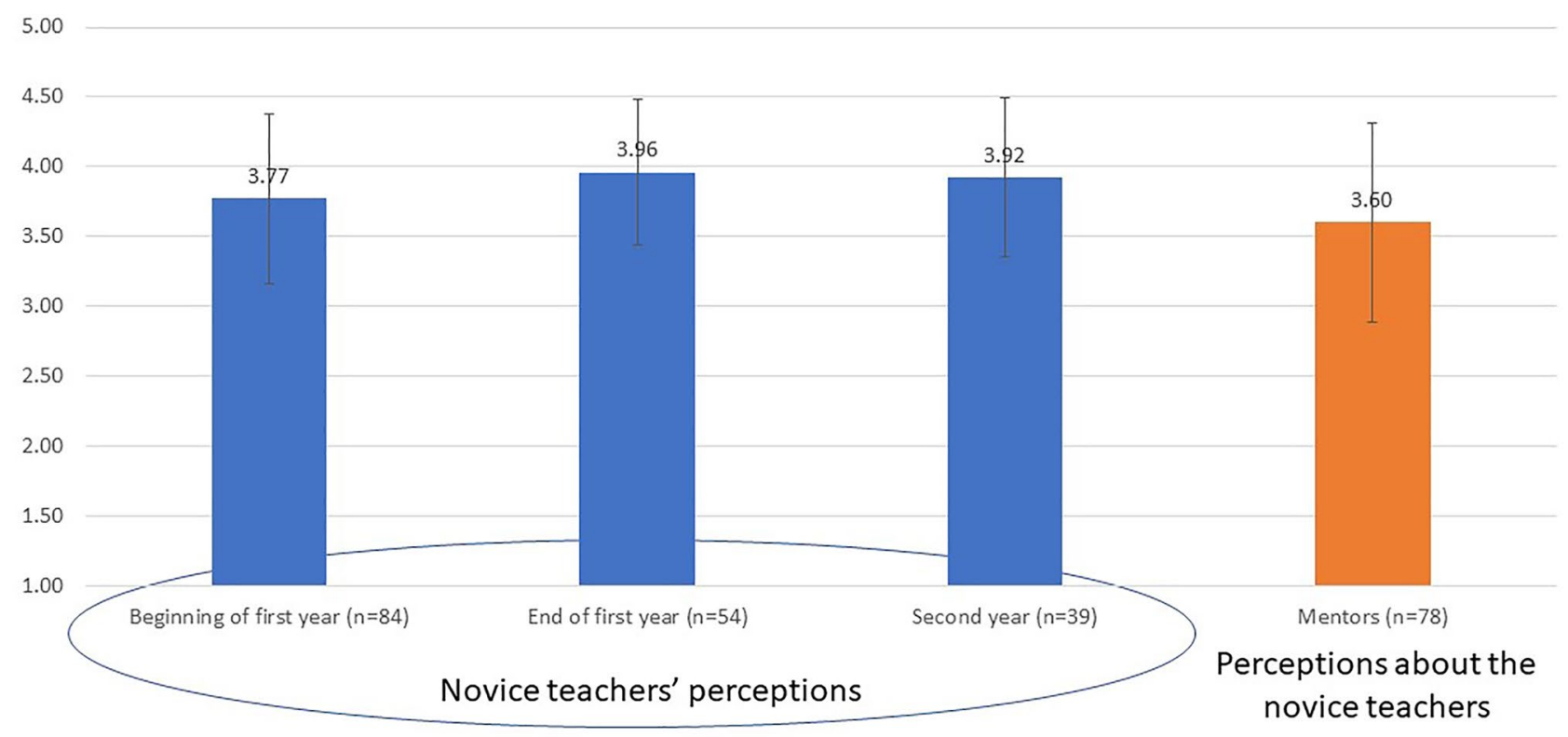

Fig. 3 Perceptions of the novice teachers and their mentors about teaching efficacy

left side columns) compared to those of the mentors (yellow, right side columns). The major differences were in the PK (middle column) and modeling factors (second column from the right). Due to these differences, the teachers were encouraged to discuss the gap in expectations and try to overcome it. The discussion helped communicate the needs and improve the communication and mentoring processes.

To analyze these differences in a quantitative manner, we used the MEPST instrument (see Table 1). We compared novice teachers' perceptions to those of the mentors. A significant difference was found between the perceptions of the mentors $(M=3.95, S D=.71)$ and the novice teachers $(M=3.57, S D=.82)$ in the PK factor $(t=-2.46, p<.05)$, as shown in Fig. 5. The differences for the modeling factor were borderline $(t=-1.73, p=0.08)$. These results reflect the trends that emerged from the workshop discussions.

We grouped the mentoring factors into the personal (personal attributes), professional (system requirements and
PK), and social (modeling and feedback) dimensions of professional development (Bell \& Gilbert, 1994). Figure 6 presents the correlations between these three dimensions and teaching efficacy. Teaching efficacy also correlated with general self-efficacy ( $r=0.411 * * *)$.

The significant correlations found for teaching efficacy show that development in a certain factor group correlated with development in the other factor groups, as well as with teaching efficacy.

Table 3 presents examples that demonstrate the meaning of personal, professional, and social growth.

\section{Perceptions Regarding the Contribution of the Mentoring to PG}

To evaluate the contribution of mentoring to the PG dimensions, 635 statements from interviews and focus groups were coded according to the support level and the growth

Table 2 Examples of statements which describe the mentoring factors

\begin{tabular}{ll}
\hline Factor & Statement \\
\hline $\begin{array}{l}\text { Personal attributes } \\
\text { System requirements }\end{array}$ & $\begin{array}{l}\text { "I bring my ideas, she (the mentor) brings her ideas; we have a partnership" [mentee-50001820213] } \\
\text { [mentee-50001820213] }\end{array}$ \\
Pedagogical knowledge "He needed my support in understanding and applying his knowledge to fit the children's abilities" \\
[mentor-50319821312] \\
$\begin{array}{l}\text { "I wodeling } \\
\text { Feedback }\end{array}$ \\
$\begin{array}{l}\text { "I presented my lesson plan, and she gave me many suggestions for improvement... it was a good lesson... afterwards } \\
\text { she gave me detailed feedback" [mentee-24100911002] }\end{array}$
\end{tabular}




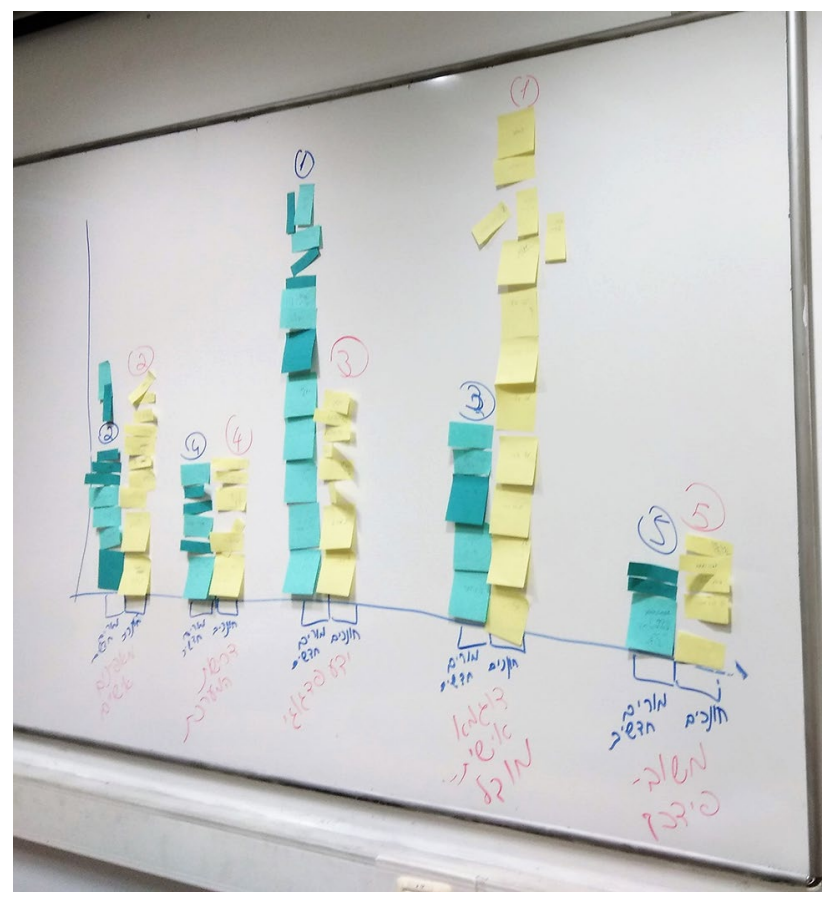

Fig. 4 Perceptions of STEM mentors and mentees regarding the topics they should discuss during the mentoring process

dimension. The evidence of PG, presented in Fig. 7, is arranged by the three levels of mentoring: personal, group, and network with examples that demonstrate the teachers' support system. We found an additional support level, selfsupport, which relates to actions that teachers initiated to support themselves.

The self-support level contains statements, in which teachers referred to their own actions or to the feelings that promoted their PG. This self-support level is based on the teachers' self-efficacy and contributes mainly to the personal dimension. As can be seen from Fig. 7, individual mentoring makes the greatest contribution to all three growth dimensions and constitutes more than $50 \%$ of the overall growth. The mentoring network contributes about half as much as the individual mentoring, which is especially interesting because it is usually based on relationships created by the teachers themselves. Group mentoring contributes primarily to the professional development, and usually focuses on pedagogical, assessment, or PCK aspects.

\section{Discussion}

Teachers' PG is a continuous process that develops primarily during the early teaching years but continues throughout the teacher's entire career. This process is especially important because a teacher's growth contributes to those around him (Avalos, 2011; Taylor, 2020).

With respect to teaching efficacy, findings show a gradual increase among novice teachers in their first year, yet there was a significant difference between their own sense of efficacy and the degree of efficacy perceived by their mentors. Teachers' experiences over the years provide them with opportunities to practice and improve their skills and enhance their efficacy (Bandura, 2012; Siwatu, 2007). The more experienced mentors, who probably have higher teaching efficacy as they have accumulated more teaching years and participated in professional development workshops (Bray-Clark $\&$ Bates, 2003), see the challenges faced by novice teachers and how much they can still grow, and therefore perceive their efficacy as lower than the self-perceived efficacy of the novice teachers themselves (Wenner, 2001). This gap also gives the mentors a sense of importance, as they feel they
Fig. 5 Perception of mentoring factors among mentors and mentees

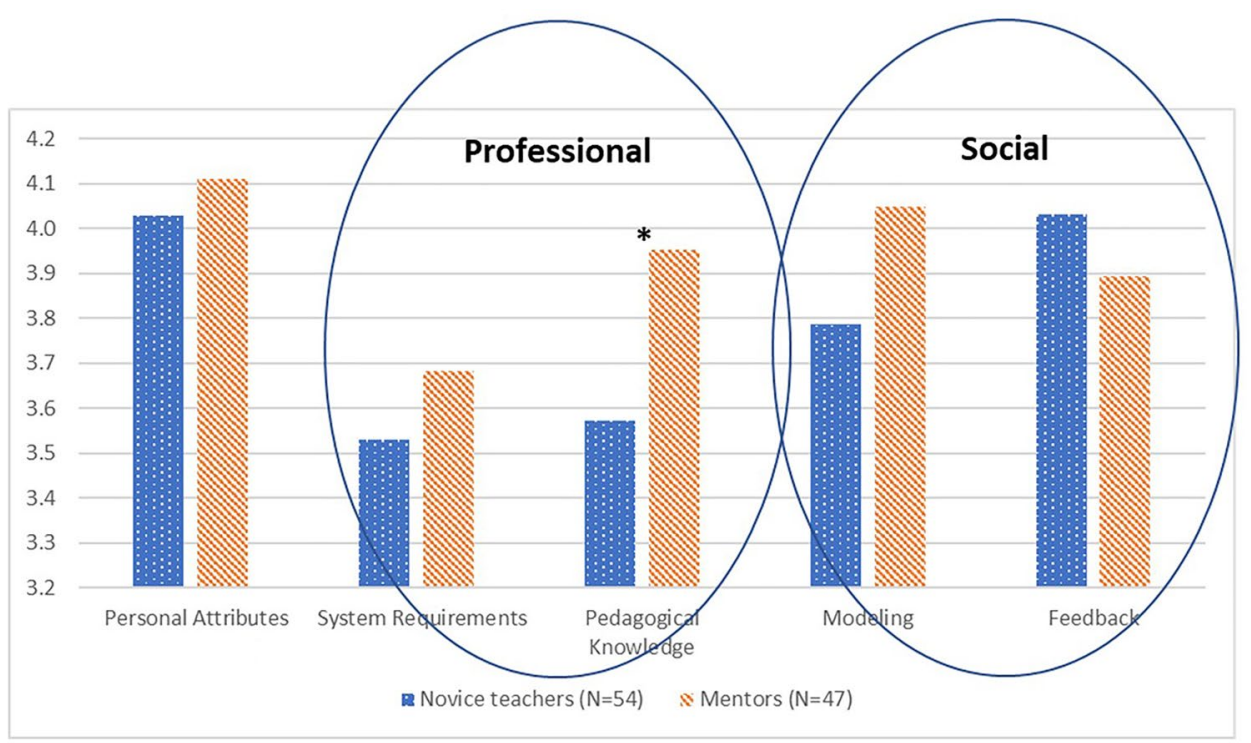


Fig. 6 Teaching efficacy and mentoring factors' Pearson correlation $(N=101)$. $* * p<0.01$, $* * * p<0.001$

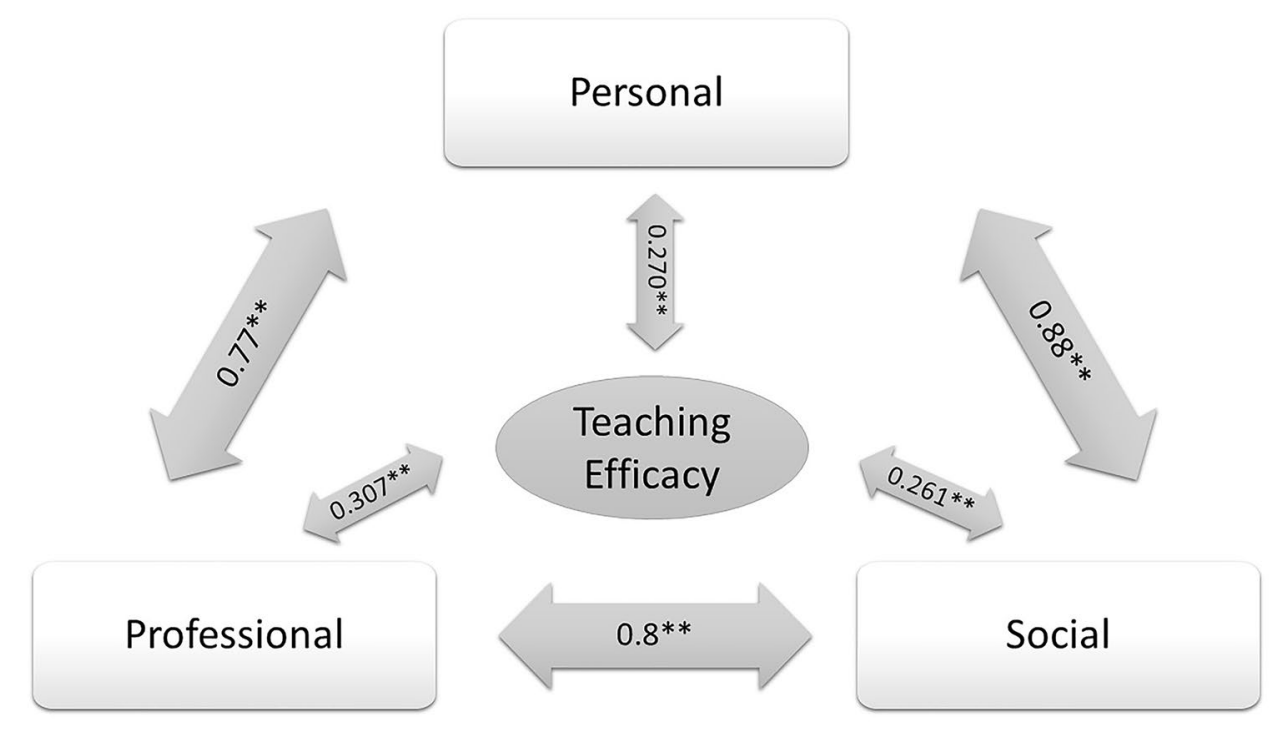

can contribute and help the mentees develop, reinforcing their own sense of meaning (Aspfors \& Fransson, 2015). For example, a mentor commented on her mentee: "The way I want a novice teacher to develop is like she developed. This includes personal responsibility, initiation, seeing the wider picture regarding what the student gets and how to promote him." [50519821223].

With respect to the mentoring process, when comparing the mentors' and mentees' perceptions, we found gaps in the value teachers attribute to PK and the modeling factors. These differences can be explained by different perceptions of the mentoring components or different definitions for the same components. This gap between mentors and mentees may be related to the mentees' lack of experience compared to their mentors. The mentees are not always aware of how much knowledge they need. The mentors usually have better PK and an understanding of what is needed in class, as it has been found that knowledge of subject matter does not improve during the first years of teaching (Nixon et al.,
2017). The difference in the importance attributed to modeling can be explained by the expectations of the relationship, as mentees tend to prefer educational mentoring (Bradbury, 2010), that supports the novice teachers' immediate needs and long-term goals for professional development. Some of the mentors still maintain the notion of traditional mentoring, which is skill-based and goal-oriented, and focuses on the transmission of learning from one generation to the next (Fletcher \& Mullen, 2012). These gaps can be addressed by facilitating open, constructive communication between the mentors and their mentees that includes discussing their expectations of their joint work and how they would like to achieve their goals (Parker et al., 2021).

We found strong correlations between developments in the three dimensions, indicating that growth in one dimension might contribute to growth in the other dimensions. The correlation found between self-efficacy and teaching efficacy suggests that actions that increase teachers' sense of efficacy contribute to their growth as well. This finding

Table 3 Dimensions of teachers' growth

\begin{tabular}{|c|c|c|}
\hline Growth dimension & Data source & Teachers' statements \\
\hline \multirow[t]{2}{*}{ Personal } & Questionnaire & $\begin{array}{l}\text { "[a mentor should] be compassionate and treat the students as I wish my children would be treated" } \\
\text { [mentee-23801911204] }\end{array}$ \\
\hline & Interview & $\begin{array}{l}\text { "I already know she can help me, and that she has the means and experience. After watching her over the } \\
\text { year, I looked up to her as an educational expert and a homeroom teacher. I wanted to hear what she } \\
\text { had to say; I wanted her support and feedback" [mentee-50801821022] }\end{array}$ \\
\hline \multirow[t]{2}{*}{ Professional } & Questionnaire & $\begin{array}{l}\text { "[mentors must have] professional willingness, inner desire, and the ability to cope with unexpected situations" } \\
\text { [mentee-23700911103] }\end{array}$ \\
\hline & Interview & $\begin{array}{l}\text { "We had regular meetings to talk about physics. We talked about pedagogy and instruction, like teachers' } \\
\text { education" [mentor-50611820326] }\end{array}$ \\
\hline \multirow[t]{2}{*}{ Social } & Questionnaire & $\begin{array}{l}\text { "Mentoring requires interpersonal relationships, and emotional and practical support" } \\
\text { [mentee-23200911010] }\end{array}$ \\
\hline & Interview & $\begin{array}{l}\text { "I met other teachers in my situation, with similar struggles. I was exposed to many suggestions and } \\
\text { examples of coping strategies." [mentee-417221] }\end{array}$ \\
\hline
\end{tabular}




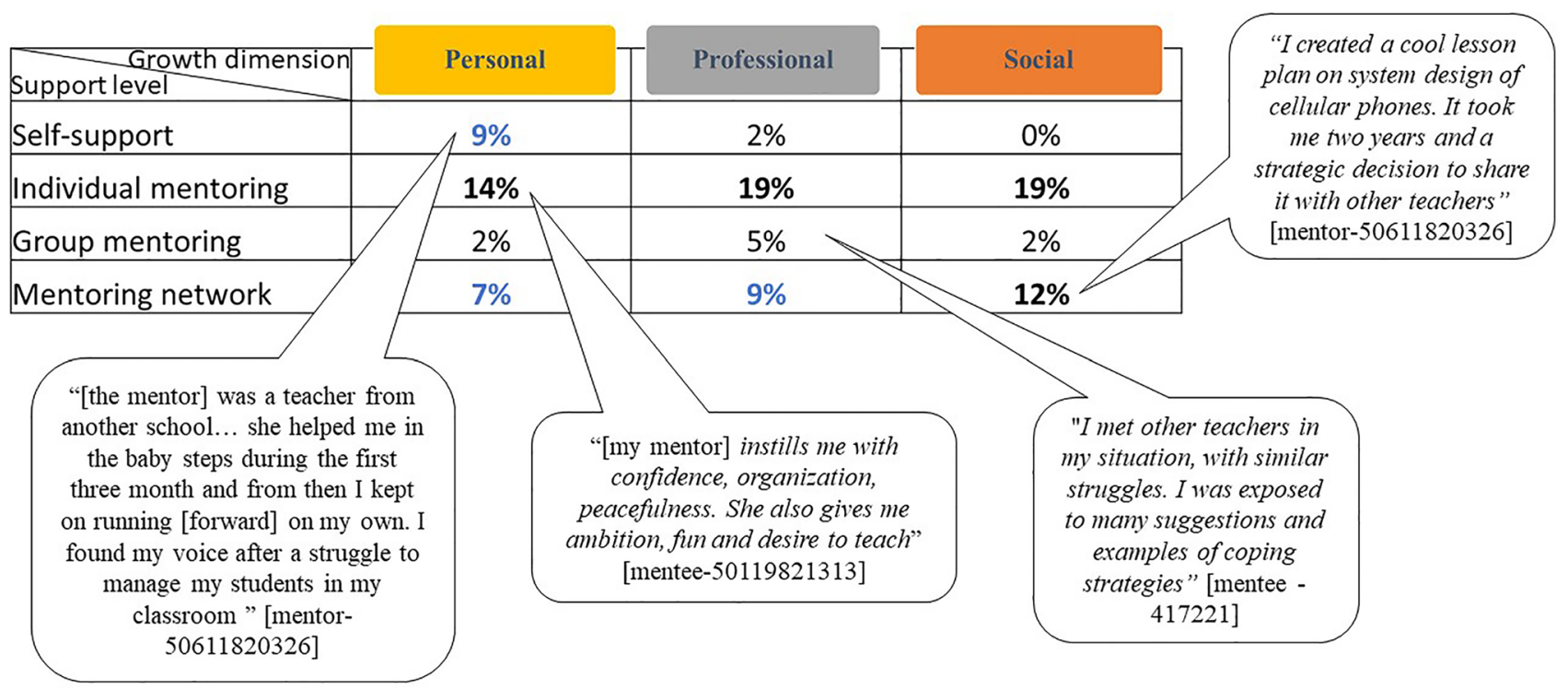

Fig. 7 The contribution of the mentoring levels to the growth dimensions

is compatible with the professional development theory, which states that the different aspects are not entirely discrete and instead, there is much interaction between them (Bell \& Gilbert, 1994). It has also been found that personal decisions made by teachers can enhance their growth, which is aligned with our findings regarding the correlations between general and teaching efficacy and the growth dimensions (Dehghan, 2020).

With regard to the contribution of the mentoring support levels to the PG, we extended the conceptual framework of Bell and Gilbert (1994) by adding the contribution of the mentoring support levels and the MEPST factors (Hudson et al., 2005) along teaching efficacy (Bandura, 2012; Jerusalem \& Schwarzer, 2014; Tschannen-Moran $\&$ Hoy, 2001, 2007). Figure 8 presents the contribution of the mentoring to each growth dimensions for each support level as a $4 \times 3$ matrix, where the number of $\mathrm{V}$ symbols in each cell in the matrix reflects the strength of the contribution each support level provides to each growth dimension: none, low, medium, and strong contributions are designated by zero, one, two, and three V's, respectively. For example, individual mentoring provides strong support to the personal growth dimension.

The three support levels address complementary needs of novice and experienced teachers that are cultivated by the social, professional, and personal growth of novice and experienced teachers (Bell \& Gilbert, 1994).

Self-support is based on actions initiated by the novice teachers in their own growth process. In the social cognitive theory, Bandura (2008) presented the perspective of the agent that forms the identity and derives how an individual acts and reflects upon it. People shape the course of events by taking action and control over their own lives and are influenced by the actions and circumstances.
Fig. 8 Contribution of each of the mentoring support level to each of the growth dimension

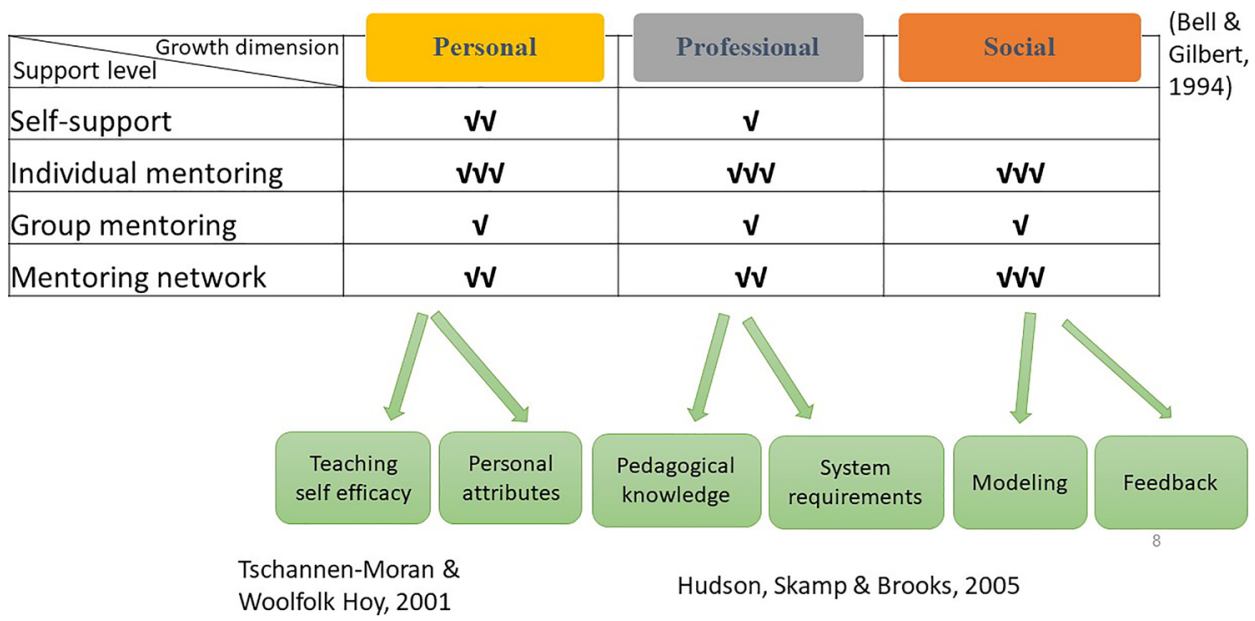


We investigated 123 novice teachers and 78 mentors. In our study and others, individual mentoring has been found to have the largest impact on the growth of teachers. Weekly meetings and continuous interactions provide mentors and mentees opportunities to establish their relationships based on dialog and reflections, contributing to the personal growth of both teachers. Fairbanks et al. (2000) investigated 15 mentors and their student teachers, and Hudson (2013) investigated 101 mentors. In both studies, similar conclusions to ours were reached regarding teachers' personal growth.

In the professional dimension, we found that personalized meetings enable the mentors to address specific disciplinebased aspects. In discussions during these meetings, both mentees and mentors articulate teaching practices that help develop their professional dimension of growth. Hudson (2013) interviewed ten mentors, all of whom stated that mentoring was a way to gain PG. Nine of them argued that the mentoring contributed to their own personal professional development as well. Shwartz and Dori $(2016,2020)$ identified three perception dimensions of mentors and novice teachers, where their professional dimension included pedagogical and content aspects. St. George and Robinson (2011) are two veteran mentors who discussed five case studies, illuminating how mentoring expands the knowledge, skills, and confidence of the novice teachers and provide PG opportunities for the mentors while improving their communication skills. Richter et al. (2013) distinguished between constructivistand transmission-oriented mentoring. The constructivistoriented mentoring, which is applied to most of the cases in their study, provided the novice teachers with support and lowered their emotional exhaustion. Collaborative work and reflection improved the novice teachers' motivation and well-being, in accord with our model regarding the social dimension of growth.

Group mentoring introduces teachers to new pedagogies, providing an opportunity to establish relationships with other teachers (Kohen \& Borko, 2019). Avalos (2011), who conducted a review of 10 years of publications on teachers' professional development, found that professional development activities, such as group mentoring, changed teachers' cognitions, beliefs, and practice. This finding is in line with our model regarding the mild contribution of group mentoring to the personal, professional, and social dimensions of growth. A professional development workshop can contribute to establishing ongoing relationships between the teachers attending them and creating a mentoring network. Mentoring networks are based on personal relationships between teachers, which develop over the years. Vozzo et al. (2004), who defined these relationships as a mentoring web, interviewed 11 retrained teachers at different time points. They found that mentoring networks provided teachers with opportunities for support when needed and not provided elsewhere. This support was on top of teachers' needs to extend their PCK, help with resources, and get emotional support from a role model. These findings are in line with ours. In our model, we found that a mentoring network helps the teacher by providing the opportunity to acquire knowledge in the professional dimension, get reflective practice in the personal dimension, and have a professional friend in the social dimension.

The induction years involve a process of learning to teach and a process of socialization (Luft et al., 2011). The combination of the three levels provides the teachers with personalized support, a peer group, in which they can see that their struggles are universal, and an opportunity to participate in a wider forum, in which they can learn and contribute as equal members of the community (Ellis et al., 2017; Vangrieken et al., 2017). Growth is facilitated by learning content-specific STEM and through pedagogical discussions. Professional development workshops promote professional development, and the administrators' guidance and clear communication are essential (Putman \& Polly, 2021). Positive relationships created in the workshops and at other opportunities are the basis for the mentoring network. It is important to understand how mentoring networks contribute to teachers' growth, particularly because they are based mostly on interactions that the teacher create on their own. These networks are often supported and maintained via social media as well (Haşiloğlu et al., 2020). In addition to the external support teachers receive, their characteristics and personality are crucial for the development of their self-efficacy, especially in the personal dimension (RameyGassert et al., 1996).

\section{Conclusions, Limitations, and Implications}

Novice teachers need effective support during the induction process. Mentorship and professional development workshops have been recognized as such. Creating a supportive community provides opportunities and scaffolds for novice and experienced teachers to grow successfully in the teaching professions (Richmond et al., 2020). Once these findings are understood, the need to create heterogeneous professional development workshops when possible becomes clear as this is the basis for a growing mentoring network in which teachers can share their unique knowledge (Trust \& Horrocks, 2017) in the personal, the professional, and the social dimensions. One limitation of our study stems from the ethical constraints, which were posed by the Israeli Ministry of Education. At the time that the study was conducted, students could not be videotaped in the classroom unless all the parents agreed to the participation of their children in the research. Therefore, we 
could not observe the teachers in action. The strength and uniqueness of this study lie in integrating the individual and group mentoring with the addition of the mentoring network. The theoretical contribution is in the extension of the professional growth model to include the mentoring support levels with an additional, fourth, self-support levels, and elucidating the interactions between them and their strength of contribution of each support level to each growth dimension. The practical contribution is in understanding the importance of the support levels and particularly a heterogeneous teachers' network, in providing scaffolds for the novice teachers that also facilitate the growth of the experienced teachers. Based on our recommendations, the education system and policy makers may encourage cooperation and sharing of learning materials and activities, by funding opportunities and infrastructure, such as workshops and conferences that can enable novice teachers to share, interact, and create networks with a variety of mentors and peers.

Acknowledgements The generous financial help of The STEM Novice Teachers' Induction Unit, Faculty of Education, Technion - Israel Institute of Technology, and The Irwin and Joan Jacobs Graduate School, Technion, Israel Institute of Technology is gratefully acknowledged.

\section{Declarations}

Ethics Approval This research has received the Technion's IRB approval \#2015-150R and 2016-28.

Consent to Participate Informed consent was obtained from all the participants in the study.

Conflict of Interest The authors declare no competing interests.

Open Access This article is licensed under a Creative Commons Attribution 4.0 International License, which permits use, sharing, adaptation, distribution and reproduction in any medium or format, as long as you give appropriate credit to the original author(s) and the source, provide a link to the Creative Commons licence, and indicate if changes were made. The images or other third party material in this article are included in the article's Creative Commons licence, unless indicated otherwise in a credit line to the material. If material is not included in the article's Creative Commons licence and your intended use is not permitted by statutory regulation or exceeds the permitted use, you will need to obtain permission directly from the copyright holder. To view a copy of this licence, visit http://creativecommons.org/licenses/by/4.0/.

\section{References}

Akiri, E., Tor, H. M., \& Dori, Y. J. (2021). Teaching and assessment methods: STEM teachers' perceptions and implementation. EURASIA Journal of Mathematics, Science and Technology Education, 17(6), em1969. https://doi.org/10.29333/ejmste/10882

Akiri, E., Tal, M., Peretz, R., Dori, D., \& Dori, Y. J. (2020). STEM graduate students' systems thinking, modeling and scientific understanding - the case of food production. Applied Sciences, 10(21), 7417. https://doi.org/10.3390/app10217417

Aspfors, J., \& Bondas, T. (2013). Caring about caring: newly qualified teachers experiences of their relationships within the school community. Teachers and Teaching: Theory and Practice, 19(3), 243-259. https://doi.org/10.1080/13540602.2012.754158

Aspfors, J., \& Fransson, G. (2015). Research on mentor education for mentors of newly qualified teachers: a qualitative meta-synthesis. Teaching and Teacher Education, 48, 75-86. https://doi.org/10. 1016/j.tate.2015.02.004

Avalos, B. (2011). Teacher professional development in teaching and teacher education over ten years. Teaching and Teacher Education, 27(1), 10-20. https://doi.org/10.1016/j.tate.2010.08.007

Avargil, S. (2019). Learning chemistry: self-efficacy, chemical understanding, and graphing skills. Journal of Science Education and Technology, 28(4), 285-298. https://doi.org/10.1007/ s10956-018-9765-x

Avargil, S., Herscovitz, O., \& Dori, Y. J. (2012). Teaching thinking skills in context-based learning: teachers' challenges and assessment knowledge. Journal of Science Education and Technology, 21(2), 207-225. https://doi.org/10.1007/s10956-011-9302-7

Awaya, A., McEwan, H., Heyler, D., Linsky, S., Lum, D., \& Wakukawa, P. (2003). Mentoring as a journey. Teaching and Teacher Education, 19(1), 45-56. https://doi.org/10.1016/S0742-051X(02)00093-8

Bandura, A. (1986). Social foundations of thought and action. Englewood Cliffs, NJ, 1986, 23-28.

Bandura, A. (2008). Toward an agentic theory of the self. Advances in Self Research, 3, 15-49. http://www.uky.edu/ eushe2/ BanduraPubs/Bandura2008ASR.pdf

Bandura, A. (2012). On the functional properties of perceived selfefficacy revisited. Journal of Management, 38(1), 9-44. https:// doi.org/10.1177/0149206311410606

Bayar, A. (2014). The components of effective professional development activities in terms of teachers' perspective. International Online Journal of Educational Sciences, 6(2), 319-327. https:// doi.org/10.15345/iojes.2014.02.006

Bell, B., \& Gilbert, J. (1994). Teacher development as professional, personal, and social development. Teaching and Teacher Education, 10(5), 483-497. https://doi.org/10.1016/0742-051X(94) 90002-7

Bower-Phipps, L., Klecka, C. V. S., \& Sature, A. L. (2016). Developing mentors: an analysis of shared mentoring practices. New Educator, 12(3), 289-308. https://doi.org/10.1080/1547688X.2016.1187979

Bradbury, L. U. (2010). Educative mentoring: promoting reform-based science teaching through mentoring relationships. Science Education, 94(6), 1049-1071. https://doi.org/10.1002/sce.20393

Bray-Clark, N., \& Bates, R. (2003). Self-efficacy beliefs and teacher effectiveness: Implications for professional development. The Professional Educator, XXVI(1), 13-22. https://eric.ed.gov/?id= EJ842387

Byars-Winston, A., \& Dahlberg, M. L. (2019). The science of effective mentorship in STEMM. Consensus Study Report. In A. ByarsWinston \& M. L. Dahlberg (Eds.), National Academies Press. ERIC. https://doi.org/10.17226/25568

Canipe, M. M., \& Gunckel, K. L. (2020). Imagination, brokers, and boundary objects: interrupting the mentor-preservice teacher hierarchy when negotiating meanings. Journal of Teacher Education, 71(1), 80-93. https://doi.org/10.1177/0022487119840660

Creswell, J. W., \& Creswell, J. D. (2017). Research design: Qualitative, quantitative, and mixed methods approaches. Sage publications.

Creswell, J. W., \& Clark, V. L. P. (2017). Convergent parallel mixed methods approach (3rd edn.). SAGE Publications.

Dehghan, F. (2020). Teachers' perceptions of professionalism: a topdown or a bottom-up decision-making process? Professional Development in Education, O0(00), 1-10. https://doi.org/10.1080/ 19415257.2020.1725597 
Dori, Y. J., \& Herscovitz, O. (2005). Case-based long-term professional development of science teachers. International Journal of Science Education, 27(12), 1413-1446. https://doi.org/10.1080/ 09500690500102946

Ellis, J., Polizzi, S. J., Roehrig, G., \& Rushton, G. (2017). Teachers as leaders: the impact of teacher leadership supports for beginning teachers in an online induction program. Journal of Technology and Teacher Education, 25(3), 245-272. https://www.learntechlib. org/p/174193/

Fairbanks, C. M., Freedman, D., \& Kahn, C. (2000). The role of effective mentors in learning to teach. Journal of Teacher Education, 51(2), 102-112. https://doi.org/10.1177/002248710005100204

Falloon, G., Hatzigianni, M., Bower, M., Forbes, A., \& Stevenson, M. (2020). Understanding K-12 STEM education: a framework for developing STEM literacy. Journal of Science Education and Technology, 29(3), 369-385. https://doi.org/10.1007/ s10956-020-09823-x

Fantilli, R. D., \& McDougall, D. E. (2009). A study of novice teachers: challenges and supports in the first years. Teaching and Teacher Education, 25(6), 814-825. https://doi.org/10.1016/j.tate.2009. 02.021

Feiman-Nemser, S. (2012). Beyond solo teaching. Educational Leadership, 69(8), 10-16. https://bir.brandeis.edu/bitstream/handle/ 10192/35953/Beyond-Solo-Teaching-Ed-Leadership.pdf

Fitzgerald, M. M., \& Theilheimer, R. (2013). Moving toward teamwork through professional development activities. Early Childhood Education Journal, 41(2), 103-113. https://doi.org/10.1007/ s10643-012-0515-z

Fletcher, S., \& Mullen, C. A. (2012). Sage handbook of mentoring and coaching in education. Sage.

Geva-May, I., \& Dori, Y. J. (2006). Analysis of an induction model. British Journal of in-Service Education, 22(3), 335-356. https:// doi.org/10.1080/0305763960220308

Haney, J. J., \& Lumpe, A. T. (1995). A teacher professional development framework guided by reform policies, teachers' needs, and research. Journal of Science Teacher Education, 6(4), 187-196. https://doi.org/10.1007/BF02614642

Haşiloğlu, M. A., Çalhan, H. S., \& Ustaoğlu, M. E. (2020). Determining the views of the secondary school science teachers about the use of social media in education. Journal of Science Education and Technology, 29(3), 346-354. https://doi.org/10.1007/ s10956-020-09820-0

Hudson, P. (2004). Toward identifying pedagogical knowledge for mentoring in primary science teaching. Science Education, 13(2). https://doi.org/10.1023/B:JOST.0000031260.27725.da

Hudson, P. (2013). Mentoring as professional development: growth for both mentor and mentee. Professional Development in Education, 39(5), 771-783. https://doi.org/10.1080/19415257.2012.749415

Hudson, P., Skamp, K., \& Brooks, L. (2005). Development of an instrument: mentoring for effective primary science teaching. Science Education, 89(4), 657-674. https://doi.org/10.1002/sce.20025

Janssen, N., \& Lazonder, A. W. (2015). Implementing innovative technologies through lesson plans: what kind of support do teachers prefer? Journal of Science Education and Technology, 24(6), 910-920. https://doi.org/10.1007/s10956-015-9573-5

Jerusalem, M., \& Schwarzer, R. (2014). Self-efficacy as a resource factor in stress appraisal processes. In R. Schwarzer (Ed.), Self-efficacy thought control of action. https://doi.org/10.4324/9781315800820

Ketelhut, D. J., Mills, K., Hestness, E., Cabrera, L., Plane, J., \& McGinnis, J. R. (2020). Teacher change following a professional development experience in integrating computational thinking into elementary science. Journal of Science Education and Technology, 29(1), 174 188. https://doi.org/10.1007/s10956-019-09798-4

Kohen, Z., \& Borko, H. (2019). Classroom discourse in mathematics lessons: the effect of a hybrid practice-based professional development program. Professional Development in Education 1-18. https://doi.org/10.1080/19415257.2019.1706186

Laudonia, I., Mamlok-Naaman, R., Abels, S., \& Eilks, I. (2018). Action research in science education-an analytical review of the literature. Educational Action Research, 26(3), 480-495. https://doi. org/10.1080/09650792.2017.1358198

Lehavi, Y., Merzel, A., Segal, R., Baram, A., \& Eylon, B. -S. (2019). Using self-video-based discourse in training physics teachers. In E. McLoughlin \& P. van Kampen (Eds.), Concepts, strategies and models to enhance physics teaching and learning (pp. 159-169). Springer International Publishing. https://doi.org/10.1007/978-3030-18137-6_14

Luft, J. A., Firestone, J. B., Wong, S. S., Ortega, I., Adams, K., \& Bang, E. (2011). Beginning secondary science teacher induction: a two-year mixed methods study. Journal of Research in Science Teaching, 48(10), 1199-1224. https://doi.org/10.1002/tea.20444

Lumpkin, A. (2008). Three keys to success for principals (and their teachers). Kappa Delta Pi Record, 45(1), 22-25. https://doi.org/ 10.1080/00228958.2008.10516527

Magnusson, S. J., Krajcik, J., \& Borko, H. (1999). Nature, sources, and development of pedagogical content knowledge for science teaching. In J. Gess-Newsome \& N. G. Lederman (Eds.), Examining pedagogical content knowledge: The construct and its implications for science education (pp. 95-132). Springer Netherlands. https://doi.org/10.1007/0-306-47217-1_4

Mandrikas, A., Michailidi, E., \& Stavrou, D. (2021). In-service teachers' needs and mentor's practices in applying a teaching-learning sequence on nanotechnology and plastics in primary education. Journal of Science Education and Technology. https://doi.org/10. 1007/s10956-021-09908-1

McTighe, J., \& Emberger, M. (2006). Teamwork on assessments creates powerful professional development. Journal of Staff Development, 27(1), 38-44. https://search.proquest.com/docview/211516663

Miedijensky, S., \& Sasson, I. (2020). Participatory action research as a way to innovate mathematics and science teaching, teachers' professional development perceptions and performances. $E d u$ cational Action Research, O0(00), 1-22. https://doi.org/10.1080/ 09650792.2020 .1802320

Mullen, C. A. (2000). Constructing co-mentoring partnerships: walkways we must travel. Theory into Practice, 39(1). https://doi.org/ 10.1207/s15430421tip3901_2

Nixon, R. S., Hill, K. M., Luft, J. A., Nixon, R. S., Hill, K. M., Luft, J. A., \& Science, S. (2017). Secondary science teachers' subject matter knowledge development across the first 5 years secondary science teachers' subject matter knowledge. Journal of Science Teacher Education, 28(7), 574-589. https://doi.org/10.1080/ 1046560X.2017.1388086

Parker, A. K., Zenkov, K., \& Glaser, H. (2021). Preparing school-based teacher educators: mentor teachers' perceptions of mentoring and mentor. Peabody Journal of Education, 96(1), 65-75. https://doi. org/10.1080/0161956X.2021.1877027

Posnanski, T. J. (2002). Professional development programs for elementary science teachers: an analysis of teacher self-efficacy beliefs and a professional development model. In Journal of Science Teacher Education (Vol. 13, Issue 3). https://doi.org/10. 1023/A: 1016517100186

Putman, S. M., \& Polly, D. (2021). Examining the development and implementation of an embedded, multi-semester internship: preliminary perceptions of teacher education candidates, clinical educators, and university faculty. Peabody Journal of Education, 96(1), 99-111. https://doi.org/10.1080/0161956X.2020.1864250

Radloff, J., \& Guzey, S. (2016). Investigating preservice STEM teacher conceptions of STEM education. Journal of Science Education and Technology, 25(5), 759-774. https://doi.org/10.1007/ s10956-016-9633-5 
Ramey-Gassert, L., Shroyer, M. G., \& Staver, J. R. (1996). A qualitative study of factors influencing science teaching self-efficacy of elementary level teachers. Science Education, 80(3), 283-315. https://doi.org/10.1002/(SICI)1098-237X(199606)80:3\%3c283:: AID-SCE2\%3e3.0.CO;2-A

Richmond, G., Bartell, T. G., Floden, R. E., \& Jones, N. D. (2020). How research sheds light on the pivotal role of mentors in teacher preparation. Journal of Teacher Education, 71(1), 6-8. https://doi. org/10.1177/0022487119887752

Richter, D., Kunter, M., Lüdtke, O., Klusmann, U., Anders, Y., \& Baumert, J. (2013). How different mentoring approaches affect beginning teachers' development in the first years of practice. Teaching and Teacher Education, 36, 166-177. https://doi.org/ 10.1016/j.tate.2013.07.012

Sachs, J. (2016). Teacher professionalism: why are we still talking about it? Teachers and Teaching: Theory and Practice, 22(4), 413-425. https://doi.org/10.1080/13540602.2015.1082732

Shulman, L. (1997). Communities of learners and communities of teachers. The wisdom of practice: Essays on teaching, learning, and learning to teach, 485-500.

Shwartz, G., \& Dori, Y. J. (2016). Looking through the eyes of mentors and novice teachers: perceptions regarding mentoring experiences. Procedia - Social and Behavioral Sciences, 228, 149-153. https://doi.org/10.1016/j.sbspro.2016.07.022

Shwartz, G., \& Dori, Y. J. (2020). Transition into Teaching: Second Career Teachers' Professional Identity. Eurasia Journal of Mathematics, Science and Technology Education, 16(11), em1891. https://doi.org/10.29333/ejmste/8502

Siwatu, K. O. (2007). Preservice teachers' culturally responsive teaching self-efficacy and outcome expectancy beliefs. Teaching and Teacher Education, 23(7), 1086-1101. https://doi.org/10.1016/j. tate.2006.07.011

St. George, C. A., \& Robinson, S. B. (2011). Making mentoring matter: perspectives from veteran mentor teachers. The Delta Kappa Gamma Bulletin, Fall, 24-29. http://web.b.ebscohost.com/ehost/ pdfviewer/pdfviewer?vid=2\&sid=752a6b86-b223-46db-bd95bb5feb92b877\%40pdc-v-sessmgr02
Tal, M., Herscovitz, O., \& Dori, Y. J. (2021). Assessing teachers' knowledge: incorporating context-based learning in chemistry. Chemistry Education Research and Practice - CERP, 22. (Online First). https://doi.org/10.1039/d0rp00359j

Taylor, P. (2020). The complexity of teacher professional growthunravelling threads of purpose, opportunity and response. Professional Development in Education 1-14. https://doi.org/10.1080/ 19415257.2020 .1747106

Trust, T., \& Horrocks, B. (2017). 'I never feel alone in my classroom': teacher professional growth within a blended community of practice. Professional Development in Education, 43(4), 645-665. https://doi.org/10.1080/19415257.2016.1233507

Tschannen-Moran, M., \& Hoy, A. W. (2001). Teacher efficacy: capturing an elusive construct. Teaching and Teacher Education, 17(7), 783-805. https://doi.org/10.1016/S0742-051X(01)00036-1

Tschannen-Moran, M., \& Hoy, A. W. (2007). The differential antecedents of self-efficacy beliefs of novice and experienced teachers. Teaching and Teacher Education, 23(6), 944-956. https://doi.org/ 10.1016/j.tate.2006.05.003

Vangrieken, K., Meredith, C., Packer, T., \& Kyndt, E. (2017). Teacher communities as a context for professional development: a systematic review. Teaching and Teacher Education, 61, 47-59. https:// doi.org/10.1016/j.tate.2016.10.001

Vozzo, L., Abusson, P., Steele, F., \& Watson, K. (2004). Mentoring retrained teachers: extending the web. Mentoring and Tutoring: Partnership in Learning, 12(3), 335-351. https://doi.org/10.1080/ 030910042000275945

Wenner, G. (2001). Science and mathematics efficacy beliefs held by practicing and prospective teachers: a 5-year perspective. Journal of Science Education and Technology, 10(2), 181-187. https://doi. org/10.1023/A:1009425331964

Zacarian, D., \& Silverstone, M. (2015). In it together: How student, family, and community partnerships advance engagement and achievement in diverse classrooms. Corwin Press.

Publisher's Note Springer Nature remains neutral with regard to jurisdictional claims in published maps and institutional affiliations. 